\title{
O ZAKRESIE PODMIOTOWYM PRAWA PRACY Z PERSPEKTYWY KONCEPCJI WORK-LIFE BALANCE
}

\begin{abstract}
Streszczenie. W Polsce znaczna część osób zatrudnionych na innej podstawie prawnej niż stosunek pracy świadczy pracę w warunkach zależności ekonomicznej. Z drugiej strony następuje odejście od klasycznego modelu podporządkowania pracowniczego, co wiąże się z większą niezależnością pracowników i stanowi konsekwencję rozwoju nietypowych form zatrudnienia także $\mathrm{w}$ ramach stosunku pracy. Biorąc to pod uwagę, warto zastanowić się, jak w przyszłości powinien się kształtować zakres podmiotowy prawa pracy. Pozycja społeczna wszystkich osób, dla których praca stanowi podstawowe źródło dochodów, a więc warunek godnego życia, jest coraz bardziej podobna, a negatywne następstwa konfliktów pomiędzy sferą życia zawodowego i prywatnego są tak samo dotkliwe, bez względu na podstawę prawną zatrudnienia. Interes społeczny wymaga więc, aby uwzględnić zagrożenia towarzyszące różnym formom świadczenia pracy.
\end{abstract}

Słowa kluczowe: umowy cywilnoprawne, bezpieczeństwo socjalne, elastyczność zatrudnienia, work-life balance, zakres podmiotowy prawa pracy.

\section{UWAGI WSTEPNE}

Granice między życiem zawodowym a życiem prywatnym człowieka w coraz większym stopniu ulegają zatarciu, na co wpływa wiele czynników o różnorodnym charakterze. W miarę rozwoju nowoczesnych technologii praca staje się pod pewnymi względami bardziej elastyczna, a przez to zarówno pracodawcy, jak i pracownicy mogą ją lepiej dostosowywać do swoich potrzeb. Dokonujący się postęp technologiczny niesie jednak również zagrożenia, przede wszystkim z tego względu, iż możliwość nieograniczonego w czasie i przestrzeni kontaktu pracodawcy z pracownikiem może prowadzić do nadmiernego angażowania człowieka w pracę, co bezpośrednio oddziałuje na możliwość wypełniania obowiązków w pozostałych, pozazawodowych sferach życia. Konflikt ról nie tylko wpływa negatywnie na jakość relacji rodzinnych czy towarzyskich, lecz stanowi także poważne zagrożenie dla dóbr osobistych w postaci zdrowia czy prawa do prywatności. Pracownik, który mentalnie również poza godzinami pracy pozostaje w sferze życia zawodowego, nie jest w stanie efektywnie wypoczywać, czemu sprzyja presja ciągłego pozostawania on-line i związane $\mathrm{z}$ tym przenoszenie często

*Uniwersytet Łódzki, Wydział Prawa i Administracji, Katedra Prawa Pracy, aleksandra. karolina.p@gmail.com 
negatywnych emocji towarzyszących pracy na sferę życia prywatnego. Problem braku równowagi pomiędzy poszczególnymi obszarami ludzkiego życia dotyka w szczególności osoby, które w większym zakresie korzystają ze swobody w planowaniu dnia pracy (Binniger 2014, 39), czyli przede wszystkim zatrudnione na podstawie umów cywilnoprawnych, ze względu na brak podporządkowania organizacyjnego.

Wśród czynników w znacznym stopniu oddziałujących na współczesny rynek pracy, a więc również na sytuację prawną jego uczestników, na pierwszy plan wysuwają się także kwestie społeczne, które już teraz prowadzą do zmian nieodwracalnych w perspektywie najbliższych lat. Jako przykład wskazać można zmiany demograficzne, które w negatywny sposób odbijają się na strukturze wiekowej społeczeństwa. Polska znajduje się obecnie na takim etapie rozwoju demograficznego, że nawet wzrost współczynnika dzietności do poziomu gwarantującego prostą zastępowalność pokoleń nie spowoduje w krótkim okresie zwiększenia liczby ludności kraju i nie zahamuje postępującego starzenia się społeczeństwa (Główny Urząd Statystyczny 2014, 33). Sytuację komplikuje dodatkowo zależność finansowa młodych ludzi, którzy często mieszkają wspólnie z rodzicami, co wynika $\mathrm{z}$ faktu, iż wykonywanie pracy zarobkowej nie zawsze wiąże się z osiąganiem dochodów pozwalających na usamodzielnienie się (Centrum Badania Opinii Społecznej 2017, 5-6). Problem ten dodatkowo pogłębia brak stabilności socjalnej, niezbędnej do realizacji planów związanych z rodzicielstwem, co w szczególności dotyczy młodych ludzi zatrudnionych na podstawie umów cywilnoprawnych, nieposiadających gwarancji zatrudnienia, a także pozbawionych możliwości zaciągnięcia kredytu na zakup własnego mieszkania. Można powiedzieć, że w coraz szerszym zakresie mamy do czynienia z postępującą prekaryzacją umów, których cechą charakterystyczną jest przypadkowość oraz niemożność tworzenia stabilnych warunków życia pracowników (Godlewska-Bujok 2014, 5). Należy zatem zgodzić się z poglądem, że nawet nowelizacja art. 22 ustawy z 26 czerwca 1974 r. Kodeks Pracy (Dz.U. 2018, poz. 917 ze zm.), doprecyzowująca cechy umowy o pracę, nie doprowadziła do ograniczenia zjawiska nieuzasadnionego zawierania umów cywilnoprawnych. W aktualnie istniejących warunkach społeczno-ekonomicznych ich stosowanie w praktyce nadal budzi liczne wątpliwości, przede wszystkim z tego względu, że faktyczna pozycja i obowiązki osób świadczących pracę na podstawie tego rodzaju umów świadczą o tym, że znaczna ich część zawierana jest sprzecznie $\mathrm{z}$ ich istotą (Salwa 2002, 207).

Przed współczesnym prawem pracy stoi zatem jedno z najważniejszych wyzwań - określenie zakresu podmiotowego kodeksu pracy, w sytuacji gdy znaczna liczba osób, dla których praca stanowi podstawowe źródło dochodów, świadczy ją w ramach tzw. elastycznych form zatrudnienia, również niepracowniczych, wśród których dominują umowy zlecenia, czy szerzej umowy nienazwane, a do tego rodzaju umów stosuje się przepisy kodeksu cywilnego dotyczące umów zlecenia (Główny Urząd Statystyczny 2016, 4). Takie osoby są w związku z tym 
pozbawione uprawnień, których minimalny standard wyznaczają przepisy prawa pracy, nawet jeśli niektóre z nich można uznać za niedoskonałe. Rodzi to potrzebę podjęcia działań, które z jednej strony zapewnią pożądaną przez pracodawców elastyczność, z drugiej - bezpieczeństwo socjalne osób, dla których praca, bez względu na podstawę zatrudnienia, stanowi warunek godnego życia. Stabilizacja socjalna pozostaje zaś w ścisłym związku z realizacją założeń koncepcji worklife balance, gdyż jak trafnie wskazuje się w doktrynie, stanowi ona gwarancję ochrony zdrowia pracownika, możliwości wypełniania przez niego socjalnych funkcji, w szczególności rodzicielskich oraz jego uczestnictwa w życiu społecznym, kulturalnym i politycznym (Rączka 2009, 167). Elastyczność z punktu widzenia pracownika należy traktować jako dążenie do harmonijnego łączenia życia zawodowego z osobistym (Mitrus 2009, 191).

\section{POJECIE WORK-LIFE BALANCE}

W pierwszej kolejności warto wskazać, co należy rozumieć pod pojęciem work-life balance. Kategoria ta stanowi przedmiot badań wielu dyscyplin naukowych, a pojęcie jest różnie definiowane w literaturze przedmiotu. Psychologowie i socjologowie próbują przede wszystkim ustalić, jak work-life balance oddziałuje na człowieka i jego środowisko, oraz wskazać rolę, jaką pełni w życiu (Binniger 2014, 3; Schnieder 2013, 36). Wyniki tych badań są istotne także z perspektywy relacji zachodzących pomiędzy elastycznością zatrudnienia a bezpieczeństwem socjalnym zatrudnionych, gdyż pozwalają ocenić celowość regulowania pewnych kwestii z zakresu work-life balance na poziomie ustawodawstwa, a także stopień szczegółowości przepisów dotyczących tej problematyki, przy uwzględnieniu specyfiki poszczególnych zakładów pracy.

Na ogół pod pojęciem work-life balance rozumie się równowagę pomiędzy życiem zawodowym a życiem prywatnym człowieka lub niewystępowanie konfliktu pomiędzy wymaganiami, z którymi człowiek styka się w obu tych sferach swojego życia (Burner 2014, 4). Wątpliwości rodzą się przede wszystkim na tle interpretacji elementów składowych tego pojęcia oraz relacji zachodzących pomiędzy sferą życia prywatnego a rodzinnego pracownika. Autorzy często zamiennie posługują się pojęciami: work-family balance czy life-domain balance, chociaż work-life balance jest pojęciem najszerszym (Burner 2014, 4-5). W czasie wolnym od pracy człowiek realizuje zobowiązania z tytułu rodzicielstwa, pełni funkcje opiekuńcze w stosunku do starszych i chorych członków rodziny, a poza tym podejmuje różnego rodzaju aktywności służące samodoskonaleniu i regeneracji sił psychofizycznych.

Czas wolny od pracy, określany jako life, przynależący do sfery prywatnej człowieka, obejmuje więc życie osobiste jednostki, kontakty towarzyskie, a także życie rodzinne, w ramach którego człowiek wykonuje również pracę 
niezarobkową, związaną z prowadzeniem gospodarstwa domowego oraz odpoczywa. Work-life balance należy więc odnosić do równowagi pomiędzy czasem poświęcanym pracy zawodowej, czasem spędzanym z rodziną i czasem przeznaczanym przez jednostkę na doskonalenie w sferze duchowej i fizycznej (Burner 2014, 5).

Pojęcie work obejmuje natomiast czynności wykonywane profesjonalnie w celu zarobkowym, w odróżnieniu od tych podejmowanych w życiu prywatnym dobrowolnie i nieodpłatnie (Burner 2014, 5). Pojęciem tym należałoby zatem objąć także pracę wykonywaną na podstawie umów cywilnoprawnych. Nie tylko większa swoboda w planowaniu dnia pracy, ale także brak gwarancji zmierzających do zapewnienia tej kategorii zatrudnionych minimalnych dobowych i tygodniowych okresów odpoczynku czy ograniczeń uniemożliwiających świadczenie pracy ponad wymiar stanowiący zagrożenie dla zdrowia i życia pracownika, przesądzają o konieczności poszukiwania rozwiązań zmierzających do ochrony wszystkich osób świadczących pracę w warunkach zależności ekonomicznej.

Problem braku regulacji obejmujących ochroną osoby świadczące pracę na podstawie umów cywilnoprawnych jest więc istotnym problemem, zważywszy na gwarantowaną przepisami Konstytucji Rzeczypospolitej Polskiej z 2 kwietnia 1997 r. (Dz.U. 1997, Nr 78, poz. 483 ze zm.) ochronę pracy (art. 24), która dotyczy wszelkiej pracy, niezależnie od przewidzianych w ustawodawstwie zwykłym form prawnych stanowiących podstawę jej wykonywania, a która pozostaje w związku $\mathrm{z}$ innymi prawami gwarantowanymi konstytucyjnie, tj. prawem do bezpiecznych i higienicznych warunków pracy (art. 66, ust. 1), prawem do wypoczynku (art. 66, ust. 2), a także wyrażoną w art. 38 i art. 68 ochroną życia oraz zdrowia (Garlicki, Zubik 2016, 66). Ponadto należy wziąć pod uwagę konieczność ochrony dóbr osobistych człowieka. Realizacja tych uprawnień jest niezbędna do harmonijnego łączenia sfery życia zawodowego i osobistego, choć warto podkreślić, że dokładne określenie relacji zachodzących pomiędzy poszczególnymi obszarami ludzkiego życia nie jest możliwe. Niewątpliwie poza czasem, w którym jednostka realizuje zobowiązania wynikające $z$ umowy, nie zawsze możliwy będzie odpoczynek od zobowiązań zawodowych. Problem ten dotyczy w szczególności osób zatrudnionych na podstawie umów cywilnoprawnych, które nie są objęte regulacjami ochronnymi z zakresu czasu pracy. Zagrożeniem w przypadku tej kategorii zatrudnionych jest jednak nie tylko brak wyraźnie zakreślonych granic, które wskazują, jak długo praca może być świadczona bez uszczerbku dla zdrowia, lecz także miejsce jej wykonywania. Zatrudniony na podstawie umowy cywilnoprawnej jest w większym stopniu narażony na przenikanie się sfery zawodowej i prywatnej, jeżeli pracuje w domu, choćby ze względu na emocje towarzyszące pracy, od których często trudno odciąć się nawet wówczas, gdy związek pomiędzy miejscem pracy a przestrzenią życia osobistego i rodzinnego zostanie zerwany. W literaturze podkreśla się, że czas, który jednostka poświęca pracy zawodowej, może prowadzić nie tylko do jej fizycznej nieobecności w domu, lecz także absorbować ją 
psychicznie w takim stopniu, że nie jest w stanie wypełniać swoich zobowiązań w życiu prywatnym, bez względu na to, gdzie się znajduje. Poza tym zachowania nabyte w sferze życia zawodowego czy prywatnego człowieka mogą nie być spójne z wymaganiami roli w innym obszarze, co sprawia, że przemieszczając się pomiędzy poszczególnymi sferami swojego życia nie zawsze jest w on w stanie dostosować je do aktualnie pełnionej roli (Lachowska 2012, 42-43).

Warto wziąć pod uwagę także fakt, że dla wielu ludzi kariera zawodowa stanowi ważny aspekt samorealizacji (Binniger 2014, 4). Obowiązki zawodowe mogą stanowić dla tych osób potężne źródło satysfakcji, co przekłada się na ogólną ocenę jakości ich życia. Możliwe jest również przenoszenie na grunt życia prywatnego negatywnych emocji towarzyszących pracy wykonywanej profesjonalnie (Argyle 2004). Za przekonujące można zatem uznać stwierdzenie, że pojęcia balance nie powinno utożsamiać się z równowagą o charakterze statycznym, gdyż poszczególne sfery ludzkiego życia przenikają się wzajemnie i zachodzą między nimi różnorodne interakcje, co czyni niemożliwą ich całkowitą separację (Gargi 2016, 82-85).

Work-life balance należy rozumieć zatem jako stan względnej równowagi pomiędzy życiem zawodowym i życiem prywatnym, które obejmuje z kolei sferę życia rodzinnego i osobistego człowieka. Istota działań podejmowanych w ramach work-life balance nakierowana jest na skuteczną koordynację życia zawodowego i prywatnego, co osiąga się poprzez uwzględnienie prywatnych, społecznych, kulturalnych i zdrowotnych aspektów (Schnieder 2013, 37). Dzięki temu możliwe jest tworzenie warunków niezbędnych dla pełnego rozwoju człowieka, sprzyjających przenoszeniu pozytywnych emocji oraz wartości, których człowiek uczy się podejmując wysiłek towarzyszący pracy, eliminowaniu natomiast tych, które prowadzą do konfliktów w życiu prywatnym i zawodowym człowieka.

\section{EWOLUCJA FORM ZATRUDNIENIA I POJĘCIA PODPORZĄDKOWANIA PRACOWNICZEGO A ZAKRES OCHRONY OSÓB ŚWIADCZĄCYCH PRACE}

Problematyka stosowania umów cywilnoprawych nabiera znaczenia zwłaszcza wówczas, gdy spojrzymy na nią z punktu widzenia przedsiębiorców oraz osób, które utrzymują się dzięki zarobkom uzyskiwanym z działalności zawodowej. Biorąc pod uwagę, że Polacy są w znacznym stopniu uzależnieni od dochodów osiąganych z pracy, gdyż z reguły posiadają niewielkie własne zasoby majątkowe - godna płaca jest istotnym elementem bezpieczeństwa socjalnego, choć nie jedynym (Dzienisiuk 2016, 85). Równie istotne jest tworzenie gwarancji w zakresie ochrony zdrowia, możliwości realizowania funkcji socjalnych, przede wszystkim rodzicielskich, oraz warunków sprzyjających uczestnictwu w życiu politycznym, społecznym i kulturalnym (Rączka 2009, 167). 
W doktrynie podkreśla się, że forma i zakres działalności zarobkowej są zwykle tymi czynnikami, które określają rolę społeczną człowieka, zarówno pod względem zatrudnienia, jak i stylu życia oraz środowiska społecznego (Dzienisiuk 2016, 85). Z perspektywy zatrudnionych istotne jest więc zarówno bezpieczeństwo ekonomiczne, jak również ilość czasu, którym mogą swobodnie dysponować. Czas wolny od pracy nie tylko stanowi warunek realizacji prawa do wypoczynku. Jego ilość determinuje także aktywność jednostki w życiu prywatnym, społecznym, kulturalnym i politycznym, co wpływa na fizyczny, duchowy i społeczny rozwój człowieka. Dla pracodawców natomiast istotne jest przede wszystkim obniżenie kosztów pracy.

W związku z tym pojawia się pytanie o granice liberalizacji prawa pracy, co wiąże się z postulatami uchylenia części przepisów, przede wszystkim tych stanowionych przez państwo, bądź umożliwienia stronom stosunków pracy odejścia od przepisów ustawowych także na niekorzyść pracownika (Florek 2003, 9). Biorąc pod uwagę głoszone pod hasłem zmniejszenia kosztów pracy żądania uelastycznienia prawa pracy, które mają na celu osłabienie ochronnej funkcji prawa w tej kwestii i zapewnienie pracodawcom większej możliwości swobodnego dysponowania osobą pracownika, należy zastanowić się, w jakim zakresie korzystne z perspektywy ogółu zatrudnionych i pracodawców będzie ograniczenie bądź obniżenie poziomu różnego rodzaju uprawnień pracowniczych, przy jednoczesnym objęciu ochroną tych grup zatrudnionych, których prawa i obowiązki wynikające z pracy zostały zróżnicowane ze względu na formalną stronę wykonywania pracy (Salwa 2002, 300). Problem ten jest dostrzegany w doktrynie prawa pracy, gdzie wskazuje się, że w kodeksie pracy powinny znaleźć się unormowania dotyczące niepracowniczego zatrudnienia, regulujące sytuację osób, które faktycznie wykonują pracę stale za wynagrodzeniem w warunkach zbliżonych do tych, które wynikają ze stosunku pracy (Sanetra 2002, 314).

Być może warto ograniczyć zakres podmiotowy szczególnej ochrony trwałości stosunku pracy ze względu na pełnione funkcje i objąć ochroną tylko tych pracowników, którzy z tytułu pełnienia określonej funkcji mogą być zagrożeni rozwiązaniem stosunku pracy (Lewandowski 2003, 33). W kodeksie pracy mogłyby znaleźć się natomiast regulacje dotyczące obowiązków pracodawcy ułatwiających harmonijne łączenie ról w różnych sferach ludzkiego życia, które powinny obejmować także osoby wykonujące pracę na innych podstawach prawnych niż stosunek pracy. Przede wszystkim warto mieć na względzie potrzebę zmiany obecnego stanu prawnego, np. w zakresie uprawnień rodzicielskich w celu zwiększenia udziału ojców w pełnieniu funkcji rodzicielskich. Słusznie wskazuje się $w$ doktrynie, że choć dążenia ustawodawcy do poszerzenia kręgu podmiotów uprawnionych do korzystania z urlopów związanych z rodzicielstwem należy ocenić pozytywnie, to w działaniu tym nie jest on do końca konsekwentny. Po pierwsze, uprawnienia ojców do korzystania z urlopów z tytułu rodzicielstwa mają zawsze charakter fakultatywny (Latos-Miłkowska 2017, 338-339). Po drugie, 
choć ustawa z 24 lipca 2015 r. o zmianie ustawy Kodeks pracy oraz niektórych innych ustaw (Dz.U. z 2015 r., poz. 1268) zwiększa uprawnienia ojców do korzystania z urlopów związanych z rodzicielstwem i przyznaje je również ojcom nieposiadającym statusu pracownika, to dokonuje zróżnicowania sytuacji prawnej ojców-pracowników oraz ojców niebędących pracownikami w sposób budzący wątpliwości choćby z tego względu, że prawo ojca niebędącego pracownikiem jest warunkowe - może on kontynuować uprawnienia rodzicielskie, jeżeli spełniony zostanie wymóg sprawowania osobistej opieki nad dzieckiem i w tym celu przerwie on działalność zarobkową. Tego wymogu ustawodawca nie formułuje w stosunku do pracownika-ojca, który także może prowadzić dodatkową działalność zawodową, rodzącą tytuł do ubezpieczenia społecznego (Bury 2016, 244-245).

Warto rozważyć także konieczność wyrażenia expressis verbis pewnych obowiązków pracodawcy mających na celu ochronę dóbr osobistych pracowników, w szczególności zdrowia i życia, np. obowiązek przeciwdziałania zjawisku pracoholizmu. W kodeksie pracy mogłyby znaleźć się również regulacje uwzględniające w szerszym zakresie zagadnienia dotyczące zagrożeń psychospołecznych pozostających w związku ze świadczoną pracą. Ponadto określając, w jakim stopniu należy objąć ochroną zatrudnionych na innej niż stosunek pracy podstawie prawnej, warto wziąć pod uwagę znaczenie przepisów o czasie pracy dla ochrony zdrowia oraz życia. W doktrynie słusznie zwraca się uwagę na budzącą zastrzeżenia konstrukcję art. 66 Konstytucji, która rodzi wątpliwości w kwestii zakresu podmiotowego tego przepisu, podobnie jak pojęcie bezpiecznych i higienicznych warunków pracy. Biorąc pod uwagę potrzebę ochrony zdrowia i życia osób świadczących pracę, należy zgodzić się z poglądem, że pojęcie to obejmuje takie warunki pracy, które minimalizują ryzyko powstania szkody na zdrowiu fizycznym lub psychicznym pracownika, a więc także niektóre przepisy o czasie pracy. Mając na uwadze konieczność zapewnienia ochrony zatrudnionym na innej niż stosunek pracy podstawie prawnej, należy poszukiwać takiej wykładni przepisów, która pozwoli uznać prawo do ochrony pracy również w szerszym niż dotychczasowy zakresie podmiotowym (Sobczyk 2012, 286-291).

Ponadto rozważając, w jakim zakresie mechanizmy ochronne prawa pracy powinny zostać rozciągnięte na osoby świadczące pracę poza stosunkiem pracy, warto wziąć pod uwagę ewolucję zarówno form zatrudnienia, jak i pojęcia podporządkowania pracowniczego, które w coraz większym stopniu upodabnia sytuację prawną pracowników do tej, w jakiej znajdują się osoby wykonujące pracę na podstawie umów cywilnoprawnych. Jak trafnie ujął to $\mathrm{SN}$, „pojęcie podporządkowania pracownika pracodawcy ewoluuje w miarę rozwoju stosunków społecznych. W miejsce dawnego systemu ścisłego hierarchicznego podporządkowania pracownika i obowiązku stosowania się do dyspozycji pracodawcy, nawet $\mathrm{w}$ technicznym zakresie działania, pojawia się nowe podporządkowanie autonomiczne polegające na wyznaczaniu pracownikowi przez pracodawcę zadań bez ingerowania w sposób wykonywania tych zadań" (wyrok SN z 13.04.2016 r., 
II PK 81/15, LEX nr 2026397)1. Zmienia się więc sposób pojmowania pojęcia podporządkowania pracowniczego, a jednocześnie brakuje kryteriów pozwalających wyznaczyć granice między stosunkiem pracy a stosunkiem cywilnoprawnym w sposób niebudzący wątpliwości. W orzecznictwie wskazuje się z jednej strony na odejście od klasycznego modelu podporządkowania pracowniczego, z drugiej na możliwość wystąpienia cech kierownictwa i podporządkowania także w umowie zlecenia (wyrok SN z 11.09.2013 r., II PK 372/12, OSNP 2014/6/80). Podkreśla się przy tym, że nie są one takie same jak w zależności właściwej dla stosunku pracy, ale jednocześnie nie wskazuje, jakie okoliczności w konkretnym przypadku pozwalają na właściwą ocenę stanu faktycznego. Co więcej, akcentuje się dopuszczalność i równorzędność różnych form świadczenia pracy i zarobkowania w systemie prawa oraz podkreśla się, że o kwalifikacji danego stosunku prawnego jako stosunku pracy nie przesądza wystąpienie elementu zależności pracownika.

\section{PODSUMOWANIE}

Polacy coraz później stają się niezależni ekonomicznie, co sprawia, że przesuwają w czasie plany dotyczące założenia rodziny. Taki stan rzeczy wynika w dużej mierze z postaw prokreacyjnych kobiet, które decyzje dotyczące macierzyństwa przesuwają w czasie ze względu na sytuację materialną, brak mieszkania, nieodpowiedną infrastrukturę w postaci żłobków, przedszkoli i świetlic oraz niedostosowanie ich lokalizacji czy godzin pracy do potrzeb rodziców. Kobiety obawiają się również trudności w godzeniu ról zawodowych i rodzinnych (Centrum Badania Opinii Społecznej 2013, 7-10). Wydaje się jednak, że tym, co przesądza o obecnej sytuacji demograficznej Polski, jest niepewność zatrudnienia, która sprawia, iż praca zarobkowa, stanowiąca dla większości Polaków podstawowe źródło dochodów, staje się priorytetem, pochłaniając niejednokrotnie zasoby człowieka w stopniu, który uniemożliwia efektywne funkcjonowanie w pozostałych sferach życia.

Poza niekorzystnymi trendami demograficznymi zaobserwować można kształtowanie takich postaw wobec pracy, które wskutek zaburzenia równowagi pomiędzy życiem zawodowym a prywatnym prowadzą do problemów ze zdrowiem, pracoholizmu, wypalenia zawodowego, co w konsekwencji odbija się także negatywnie na efektywności i jakości pracy. Wydaje się więc właściwe, aby objąć wszystkie osoby świadczące pracę, bez względu na podstawę prawną

\footnotetext{
${ }^{1}$ Sąd Najwyższy w wyroku z dnia 20 stycznia 2016 r. (II PK 311/14, LEX nr 1974078), odnosząc się do kwestii dyscypliny pracy, obejmuje zakresem tego pojęcia obowiązek pracownika stosowania się do poleceń przełożonych, wskazując, że dotyczy on w równym stopniu pracownika wykonującego pracę w klasycznym modelu podporządkowania pracowniczego, jak i pracownika dysponującego autonomią w zakresie kształtowania swojego czasu pracy i sposobu realizacji powierzonych obowiązków.
} 
zatrudnienia, m.in. regulacjami z zakresu szeroko rozumianego BHP, a więc w pewnym zakresie również przepisami dotyczącymi czasu pracy.

Określając zakres podmiotowy prawa pracy, należy jednak wziąć pod uwagę, że wystarczy jedynie rozciągnąć mechanizmy ochronne prawa pracy na osoby, które choć nie mają statusu pracownika, charakteryzują się podobną pozycją społeczną do tej, w jakiej znajdują się pracownicy. Pozwoli to zachować tożsamość stosunku prawnego, w którym pozostają, jak i zastosować do tej kategorii zatrudnionych wybrane regulacje $\mathrm{w}$ stopniu, jaki znajduje uzasadnienie w sposobie świadczenia przez nich pracy (Góral 2015, 331). Takie rozwiązanie jest przekonujące, choć jego przyjęcie prowadzi do wniosku, że uzasadnione byłoby, aby zakres ochrony zróżnicować $\mathrm{w}$ większym stopniu również w stosunku do pracowników zatrudnionych na podstawie umowy o pracę, biorąc pod uwagę, że rozwój nietypowych form zatrudnienia postępuje także $\mathrm{w}$ ramach stosunku pracy, co wiąże się z odejściem od klasycznego modelu podporządkowania pracowniczego oraz większą niezależnością pracowników.

Ponadto należy wziąć pod uwagę, że przy postępującym uelastycznianiu rynku pracy, w Polsce brakuje rozwiązań socjalnych dla osób, które tracą pracę, co może skutkować ich wykluczeniem. Należy zgodzić się ze stwierdzeniem, iż rozwój flexicurity $w$ Polsce będzie zależał od nowoczesnych systemów zabezpieczenia społecznego, aktywnej polityki na rynku pracy oraz ukształtowania się idei kształcenia ustawicznego (Patulski 2009, 176-177). To natomiast może być trudne do zrealizowania w praktyce, przede wszystkim ze względu na konieczność finansowania świadczeń socjalnych czy różnego rodzaju szkoleń (Mitrus 2009, 193).

Postulaty de lege ferenda dotyczące rozwiązań służących harmonijnemu łączeniu życia zawodowego z prywatnym powinny więc uwzględnić rozwój elastycznych form zatrudnienia oraz szerokie zastosowanie umów cywilnoprawnych jako powszechnej podstawy umownej wykonywania pracy w Polsce (Godlewska-Bujok 2014, 5). Przede wszystkim jednak należy pamiętać, że większa elastyczność w zatrudnieniu powinna być łączona $\mathrm{z}$ działaniami służącymi zapewnieniu bezpieczeństwa socjalnego zatrudnionych. Jeśli więc dostosujemy poziom ochrony pracowników oraz zatrudnionych na innej podstawie niż stosunek pracy do warunków, w jakich świadczona jest ich praca, to należy podjąć odpowiednie działania, które pozwolą wyeliminować negatywne następstwa utraty zatrudnienia. Ponadto większa elastyczność zatrudnienia i ograniczenie stosowania mechanizmów ochronnych w ramach stosunku pracy powinny nie tylko zmniejszyć opór pracodawców do objęcia nimi także pewnych kategorii zatrudnionych na innej podstawie niż stosunek pracy. Wskazane jest, by większej elastyczności zatrudnienia towarzyszyły również działania, które poprawią warunki pracy pod kątem możliwości łączenia pracy zawodowej z życiem prywatnym, jednak przy uwzględnieniu specyfiki pracy wykonywanej przy zachowaniu większej niezależności, aby w ten sposób nie dopuścić do kształtowania destrukcyjnych postaw wobec pracy 
i związanych z tym zagrożeń dla zdrowia i życia pracowników. Wymogi interesu społecznego nakazują ustalenie, w jakim zakresie rozszerzone lub zawężone zostanie stosowanie mechanizmów ochronnych prawa pracy. To duże wyzwanie, jeśli weźmie się pod uwagę, jak liczna jest kategoria osób świadczących pracę w warunkach zależności ekonomicznej.

\section{BIBLIOGRAFIA}

Argyle, Michael. 2004. Psychologia szczęścia. Wrocław: Astrum. Podaję za: Wudarzewski, Grzegorz. 2013. „Satysfakcja z pracy - konceptualizacja pojęcia w świetle badań literaturowych”. Zeszyty Naukowe Wyższej Szkoły Bankowej we Wroctawiu 5(37): 323-344. http://yadda.icm. edu.pl/yadda/element/bwmeta1.element.desklight-d4cad932-dde1-41f5-be2b-3665269d5811 [dostęp 30.07.2018].

Binniger, Michael. 2014. Work-Life Balance als Chance gegen die demografische Entwicklung: Eine Untersuchung hinsichtlich des gegenwärtigen Fachkräftemangels. Hamburg: Diplomica Verlag. http://han3.lib.uni.lodz.pl/han/ebsco/search-1 ebscohost-1com-1002d1d5512d4.han3. lib.uni.lodz.pl/login.aspx?direct $=$ true $\& \mathrm{db}=$ nlebk $\& A N=794952 \&$ lang=pl\&site=eds-live $\quad[$ dostęp 25.06.2017].

Burner, Fabian. 2014. Work-Life Balance: Herausforderungen für die Beschäftigten vor dem Hintergrundent grenzter Arbeit und Handlungs empfehlungen zur besseren Vereinbarkeit von Berufs- und Privatleben. Hamburg: Diplomica Verlag. http://han3.lib.uni.lodz.pl/han/ebsco/ search-1ebscohost-1 com-1002d1d55127d.han3.lib.uni.lodz.pl/login.aspx?direct=true $\& \mathrm{db}=\mathrm{nl}$ ebk\&AN=794819\&lang=pl\&site=eds-live [dostęp 25.06.2017].

Bury, Beata. 2016. „Prawo ojca dziecka niebędącego pracownikiem do realizacji uprawnień rodzicielskich związanych z urlopem macierzyńskim”. Monitor Prawa Pracy 5: 244-249.

Centrum Badania Opinii Społecznej. 2013. Komunikat z badań. Postawy prokreacyjne kobiet. Warszawa: Centrum Badania Opinii Społecznej. https://www.cbos.pl/SPISKOM. POL/2013/K_029_13.PDF [dostęp 26.07.2018].

Centrum Badania Opinii Społecznej. 2017. Komunikat z badań. Petnoletnie dzieci mieszkajace z rodzicami. Warszawa: Centrum Badania Opinii Społecznej. https://www.cbos.pl/SPISKOM. POL/2017/K_098_17.PDF [dostęp 26.07.2018].

Dzienisiuk, Dorota. 2016. „Bezpieczeństwo socjalne pracowników - między gospodarką a ochroną organizowaną przez państwo". W Prawo pracy. Między gospodarka a ochrona pracy. Księga jubileuszowa Profesora Ludwika Florka. Red. Monika Latos-Miłkowska, Łukasz Pisarczyk. 85-112. Warszawa: Wolters Kluwer.

Florek, Ludwik. 2003. „Granice liberalizacji prawa pracy”. W Granice liberalizacji prawa pracy. Problemy zabezpieczenia społecznego. Red. Edyta Bielak, Henryk Lewandowski. 9-26. Łódź: Wydawnictwo Uniwersytetu Łódzkiego.

Gargi, Roy. 2016. „Impact of mobile communication technology on the work-life balance of working woman - a review of discourses". Journal of Contemporary Management Research 10(1): 79-101. http://han3.lib.uni.lodz.pl/han/ebsco/search-1ebscohost-1com-1002d1dxb115c.han3. lib.uni.lodz.pl/login.aspx?direct=true $\& \mathrm{db}=\mathrm{bth} \& \mathrm{AN}=113644339 \&$ lang=pl\&site=eds-live [dostęp 25.06.2017].

Garlicki, Lech, Marek Zubik. 2016. „Komentarz do art. 24 Konstytucji”. W Konstytucja Rzeczypospolitej Polskiej. Komentarz. Tom I. Wyd. II. Red. Leszek Garlicki, Marek Zubik. LEX. 
Garlicki, Lech, Sylwia Jarosz-Żukowska. 2016. „Komentarz do art. 66 Konstytucji”. W Konstytucja Rzeczypospolitej Polskiej. Komentarz. Tom II. Wyd. II. Red. Leszek Garlicki, Marek Zubik. LEX.

Główny Urząd Statystyczny. 2014. Sytuacja demograficzna osób starszych i konsekwencje starzenia się ludności Polski w świetle prognozy na lata 2014-2015. Warszawa: GUS. http://stat.gov.pl/ obszary-tematyczne/ludnosc/ludnosc/sytuacja-demograficzna-osob-starszych-i-konsekwencje-starzenia-sie-ludnosci-polski-w-swietle-prognozy-na-lata-2014-2050,18,1.html [dostęp 26.07.2018].

Główny Urząd Statystyczny. 2016. Pracujący w nietypowych formach zatrudnienia. Warszawa: GUS. https://stat.gov.pl/obszary-tematyczne/rynek-pracy/opracowania/pracujacy-w-nietypowych-formach-zatrudnienia,11,1.html [dostęp 26.07.2018].

Godlewska-Bujok, Barbara. 2014. „Prekariat a umowy prekaryjne. Głos w dyskusji”. Praca i Zabezpieczenie Społeczne 9: 2-6.

Góral, Zbigniew. 2015. „O zakresie podmiotowym prawa pracy w Polsce - wybrane uwagi na tle planów rekodyfikacyjnych". W Przyszłość prawa pracy. Liber Amicorum. W pięćdziesięciolecie pracy naukowej Profesora Michała Seweryńskiego. Red. Zbigniew Hajn, Dagmara Skupień. 317-334. Łódź: Wydawnictwo Uniwersytetu Łódzkiego.

Lachowska, Bogusława. 2012. Praca i rodzina: konflikt czy synergia? Konflikt i facylitacja między rolami rodzinnymi i zawodowymi - uwarunkowania i znaczenie dla jakości życia kobiet i mężczyzn. Lublin: Wydawnictwo Katolickiego Uniwersytetu Lubelskiego.

Latos-Miłkowska, Monika. 2017. „Zakres podmiotowy urlopów związanych z rodzicielstwem”. W Tendencje rozwojowe indywidualnego i zbiorowego prawa pracy. Ksiega jubileuszowa Profesora Grzegorza Goździewicza. Red. Marzena Szabłowska-Juckiewicz, Beata Rutkowska, Anna Napiórkowska. 323-339. Toruń: Towarzystwo Naukowe Organizacji i Kierownictwa „Dom Organizatora”.

Lewandowski, Henryk. 2003. „Granice liberalizacji prawa pracy”. W Granice liberalizacji prawa pracy. Problemy zabezpieczenia społecznego. Red. Edyta Bielak. Henryk Lewandowski. 27-34. Łódź: Wydawnictwo Uniwersytetu Łódzkiego.

Mitrus, Leszek. 2009. „Elastyczność zatrudnienia a stabilność socjalna. Głos w dyskusji”. W Ochrona praw człowieka $w$ świetle przepisów prawa pracy i zabezpieczenia społecznego. Red. Andrzej Marian Świątkowski. 190-194. Warszawa: C.H. Beck.

Patulski, Andrzej. 2009. „Nowe zjawiska na polskim rynku pracy a prawo pracy. Między elastycznością zatrudnienia a bezpieczeństwem socjalnym". W Ochrona praw człowieka w świetle przepisów prawa pracy i zabezpieczenia społecznego. Red. Andrzej Marian Świątkowski. 175-186. Warszawa: C.H. Beck.

Rączka, Krzysztof. 2009. „Elastyczny czas pracy a bezpieczeństwo socjalne pracowników”. W Ochrona praw człowieka $w$ świetle przepisów prawa pracy $i$ zabezpieczenia społecznego. Red. Andrzej Marian Świątkowski. 167-174. Warszawa: C.H. Beck.

Salwa, Zbigniew. 2002. „Przemiany prawa pracy początku stulecia a jego funkcja ochronna”. W Prawo pracy a wyzwania XXI wieku. Ksiegga jubileuszowa Profesora Tadeusza Zielińskiego. Red. Maria Matey-Tyrowicz, Lesław Nawacki, Barbara Wagner. 295-304. Warszawa: Biuro Rzecznika Praw Obywatelskich.

Sanetra, Walerian. 2002. „Uwagi w kwestii zakresu podmiotowego kodeksu pracy”. W Prawo pracy a wyzwania XXI wieku. Ksiega jubileuszowa Profesora Tadeusza Zielińskiego. Red. Maria Matey-Tyrowicz, Lesław Nawacki, Barbara Wagner. 305-317. Warszawa: Biuro Rzecznika Praw Obywatelskich.

Schnieder, Stefan. 2013, Work Life Balance in Unternehmen: Eine Chance im Wettbewerb um Fachkräfte. Hamburg: Diplomica Verlag. http://han3.lib.uni.lodz.p1/han/ebsco/search-1ebscohost- 
-1 com-1002d1d55127d.han3.lib.uni.lodz.pl/login.aspx?direct=true \&db=nlebk\&AN=794265 \&lang=pl\&site=eds-live [dostęp 25.06.2017].

Sobczyk, Arkadiusz. 2012. „Uwagi na tle art. 66 Konstytucji”. W Wolność i sprawiedliwość w zatrudnieniu. Księga pamiątkowa poświęcona Prezydentowi Rzeczypospolitej Polskiej Profesorowi Lechowi Kaczyńskiemu. Red. Michał Seweryński, Jakub Stelina. 285-291. Gdańsk: Wydawnictwo Uniwersytetu Gdańskiego.

\title{
Akty prawne
}

Konstytucja Rzeczypospolitej Polskiej z 2 kwietnia 1997 r. (Dz.U. 1997, Nr 78, poz. 483 ze zm.). Ustawa z dnia 26 czerwca 1974 r. Kodeks Pracy (Dz.U. 2018, poz. 917 ze zm.).

Ustawa z dnia 24 lipca 2015 r. o zmianie ustawy - Kodeks pracy oraz niektórych innych ustaw (Dz.U. 2015, poz. 1268).

\section{Orzecznictwo}

Wyrok Sądu Najwyższego z dnia 11 września 2013 r., II PK 372/12, OSNP 2014/6/80.

Wyrok Sądu Najwyższego z dnia 13 kwietnia 2016 r., II PK 81/15, LEX nr 2026397.

\section{Aleksandra Pietras}

\section{ABOUT THE SUBJECTIVE SCOPE OF LABOUR LAW FROM THE PERSPECTIVE WORK-LIFE BALANCE CONCEPT}

\begin{abstract}
In Poland, a significant number of people employed on a legal basis other than the employment relationship, carry out work in the conditions of economic dependence. On the other hand, there is a departure from the classical model of employee subordination, which is connected with greater independence of employees and is a consequence of the development of atypical forms of employment also within the employment relationship. Taking this into account, it is worth considering how the subjective scope of labour law should be shaped in the future. The social standing of all people for whom work is the basic source of income, and therefore the condition of a good life, is more and more similar, and negative consequences of conflicts between the sphere of professional and private life are equally severe regardless of the legal basis of employment. The social interest therefore requires taking into account some threats accompanying various forms of work done.
\end{abstract}

Keywords: civil law contracts, social security, flexible employment, work-life balance, personal scope of labour law. 